\title{
ANALISIS DAYA SAING KACANG HIJAU DI KECAMATAN SARONGGI KABUPATEN SUMENEP
}

\author{
Ribut Santosa ${ }^{1}{ }^{*}$ \\ 1)*Dosen Fakultas Pertanian Universitas Wiraraja Madura \\ e-mail : ributsantosa@wiraraja.ac.id ${ }^{1)^{*}}$
}

\begin{abstract}
ABSTRAK
Kacang Hijau merupakan salah satu komoditas pertanian yang banyak diusahakan oleh petani Indonesia khususnya di Kecamatan Saronggi. Kacang hijau memiliki peluang cukup terbuka diera perdagangan bebas. Hal ini ditandai dengan adanya ekspor baik berupa konsumsi segar maupun olahan yang meningkat. Keberhasilan akan ditentukan oleh keunggulan daya saing komoditas yang dihasilkan dalam menghadapi persaingan yang ketat. Tujuan penelitian. untuk mengetahui nilai keuntungan dan keunggulan serta dampak kebijakan pemerintah terhadap usahati kacang hijau. Penelitian dilakukan di Desa Saronggi Kecamatan Saronggi Kabupaten Sumenep. Untuk menganalisis hipotesis pertama, kedua dan ketiga yaitu daya saing dan dampak kebijakan pemerintah terhadap usahatani kacang hijau digunakan alat analisis matrik kebijakan atau Policy Analysis Matrix (PAM) yang dikembangkan oleh Monke dan Pearson (1989). Model ini berupa suatu matrik yang disusun dengan memasukkan komponen-komponen utamanya penerimaan, biaya, dan profit (Soetriono, 2006). Hasil analisis PAM akan memberikan informasi tentang profitabilitas, daya saing suatu komoditas baik dari efisiensi ekonomik (keunggulan komparatif) maupun efisiensi finansial, dampak kebijakan pemerintah terhadap sistem komoditi tersebut. Berdasarkan hasil analisis dan pembahasan secara spesifik dapat diambil beberapa kesimpulan sebagai berikut: 1 . Usahatani kacang hijau yang ditanam di Desa Saronggi Kecamatan Saronggi Kabupaten Sumenep menguntungkan dan mampu bersaing, serta layak untuk diusahakan. 2. Usahatani kacang hijau memiliki keunggulan komparatif dan keunggulan kompetitif. 3. Kebijakan pemerintah tidak memberikan dampak positif atau tidak berpihak baik dari segi output dan input tradable terhadap petani kacang hijau di Kabupaten Sumenep.
\end{abstract}

Kata kunci: Usahatani Kacang Hijau, Daya Saing.

\section{PENDAHULUAN}

Kacang hijau (Vigna radiata, L.) merupakan salah satu komuditas pertanian dari famili Leguminocecae yang banyak dikonsumsi oleh masyarakat dan memiliki kelebihan dibandingkan tanaman pangan lainnya. Keunggulan kacang hijau diantaranya berumur genjah (55-65 hari), tahan kekeringan, variasi jenis penyakit relatif sedikit, dapat ditanam pada lahan kurang subur dan harga jual relatif tinggi serta stabil (Hastuti dkk, 2018). Kacang hijau juga digunakan sebagai bahan baku industri, dan merupakan komuditas ekspor. Berdasarkan data Badan Pusat Statistika 
kacang hijau di Indonesia cenderung berfluktuasi dari tahun 2014 hingga 2017 dan dapat dilihat pada Tabel 1.1

Tabel 1.1 Luas Panen, Produksi dan Produktivitas Kacang Hijau di Indonesia Tahun 2014 - 2017.

\begin{tabular}{cccc}
\hline Tahun & $\begin{array}{c}\text { Luas Panen } \\
(\text { Ha) }\end{array}$ & $\begin{array}{c}\text { Produksi } \\
\text { (Ton) }\end{array}$ & $\begin{array}{c}\text { Produktivitas } \\
\text { (Ton/Ha) }\end{array}$ \\
\hline 2014 & 208.016 & 244.589 & 1,176 \\
2015 & 229.475 & 271.463 & 1,183 \\
2016 & 223.948 & 252.985 & 1,130 \\
2017 & 206.469 & 241.334 & 1,169 \\
\hline
\end{tabular}

Sumber :Badan Pusat Statistika, 2018

Ekspor kacang hijau berdasarkan data BPS secara nasional di Indonesia tahun 2018 dari Januari hingga Juni sebesar 1.625 ton mengalami kenaikan 53 persen pada tahun 2019 di periode yang sama sebesar 3.489 ton dalam bentuk segar 3.378 ton dan olahan 111 ton. Pada awal bulan September 2019 ekspor kacang hijau dari Jawa Timur ke China dan Filipina sebanyak 35 kontainer. Kepala Dinas Pertanian dan Ketahanan Pangan Jawa Timur mengatakan bahwa Sumenep, Sampang, Gresik, Sidoarjo, Bojonegoro dan Mojokerto merupakan penghasil utama kacang hijau di Jawa Timur (Balitkabi, 2019).

Kabupaten Sumenep yang termasuk dalam penghasil utama di Jawa Timur sebesar 12.492,55 ton pada tahun
2017 memiliki potensi besar untuk mengembangkan usahatani kacang hijau walaupun produksinya mengalami penurunan yang signifikan menjadi $3.995,38$ pada tahun 2018. Penurunan hasil produksi disebabkan oleh banyaknya lahan dibeberapa kecamatan tidak melakukan usahatani kacang hijau.

Salah satu penghasil kacang hijau terbesar di Kabupaten Sumenep tahun 2018 terdapat pada Kecamatan Saronggi. Berdasarkan data Badan Pusat Statistik Kabupaten Sumenep, Kecamatan Saronggi berada diurutan pertama yaitu dengan luas lahan 1.261 hektar dengan produksi $1.8844,84$ ton. Data luas panen dan produksi kacang hijau di Kabupaten Sumenep dapat dilihat pada tabel 1.2

Tabel 1.2 Luas Panen dan Produksi Kacang Hijau setiap Kecamatan di Kabupaten Sumenep. 


\begin{tabular}{|c|l|c|c|c|c|}
\hline \multirow{2}{*}{ No } & \multirow{2}{*}{ Kecamatan } & \multicolumn{2}{|c|}{$\mathbf{2 0 1 7}$} & \multicolumn{2}{c|}{$\mathbf{2 0 1 8}$} \\
\cline { 3 - 6 } & $\begin{array}{c}\text { Luas Panen } \\
\text { (Ha) }\end{array}$ & $\begin{array}{c}\text { Produksi } \\
\text { (Ton) }\end{array}$ & $\begin{array}{c}\text { Luas Panen } \\
\text { (Ha) }\end{array}$ & $\begin{array}{c}\text { Produksi } \\
\text { (Ton) }\end{array}$ \\
\hline 1 & Pragaan & 1,862 & $2,744.59$ & - & - \\
\hline 2 & Bluto & 109 & 159.79 & 89 & 130.47 \\
\hline 3 & Saronggi & 3,465 & $5,069.30$ & 1,261 & $1,844.84$ \\
\hline 4 & Giligenting & 38 & 45.37 & - & - \\
\hline 5 & Talango & 58 & 71.22 & - & - \\
\hline 6 & Kalianget & - & - & - & - \\
\hline 7 & Kota Sumenep & 40 & 52.40 & 66 & 86.59 \\
\hline 8 & Batuan & 37 & 53.06 & 82 & 118.16 \\
\hline 9 & Lenteng & 23 & 33.65 & 19 & 27.80 \\
\hline 10 & Ganding & 53 & 77.75 & 70 & 102.40 \\
\hline 11 & Guluk-Guluk & 128 & 189.82 & 50 & 74.15 \\
\hline 12 & Pasongsongan & 1,480 & $2,110.48$ & - & - \\
\hline 13 & Ambunten & 276 & 365.15 & - & - \\
\hline 14 & Rubaru & 163 & 220.21 & 61 & 82.41 \\
\hline 15 & Dasuk & 119 & 162.32 & 6 & 8.18 \\
\hline 16 & Manding & - & - & - & - \\
\hline 17 & Batuputih & 72 & 95.47 & - & - \\
\hline 18 & Gapura & 257 & 355.17 & 999 & $1,380.48$ \\
\hline 19 & Batang Batang & 82 & 107.26 & - & - \\
\hline 20 & Dungkek & 9 & 11.67 & - & - \\
\hline 21 & Nonggunong & 58 & 75.34 & 3 & 3.90 \\
\hline 22 & Gayam & 289 & 379.75 & 97 & 127.46 \\
\hline 23 & Raas & 13 & 15.86 & 7 & 8.54 \\
\hline 24 & Sapeken & 6 & 7.75 & - & - \\
\hline 25 & Arjasa & - & - & - & - \\
\hline 26 & Kangayan & 49 & 63.31 & - & - \\
\hline 27 & Masalembu & 20 & 25.86 & - & - \\
\hline & Jumlah Total & $\mathbf{8 , 7 0 6}$ & $\mathbf{1 2 , 4 9 2 . 5 5}$ & $\mathbf{2 , 8 1 0}$ & $\mathbf{3 , 9 9 5 . 3 8}$ \\
\hline
\end{tabular}

Sumber :Data sekunder diolah, 2019

Produk agribisnis khususnya kacang hijau memiliki peluang cukup terbuka diera perdagangan bebas. Hal ini ditandai dengan adanya ekspor baik berupa konsumsi segar maupun olahan yang meningkat. Keberhasilan akan ditentukan oleh keunggulan daya saing komoditas yang dihasilkan dalam menghadapi persaingan yang ketat.

Ditinjau dari posisi strategis tersebut, maka usahatani kacang hijau seharusnya diusahakan dengan baik sehingga dapat meningkatkan keuntungan dan memiliki daya saing. Keunggulan komparatif dan keunggulan kompetitif merupakan indikator daya saing dari suatu komoditas. Keduanya harus saling berkaitan dan mendukung satu sama lain.

Dari uraian tersebut maka penulis ingin meneliti mengenai profitabilitas usahatani dan daya saing kacang hijau di Kecamatan Saronggi Kabupaten Sumenep.

Rumusan Masalah

Adapun rumusan masalah dari latar belakang yaitu sebagai berikut :

1. Apakah komoditas Kacang hijau menguntungkan bagi petani Kacang hijau di Kabupaten Sumenep.

2. Apakah komoditas Kacang hijau di Kabupaten Sumenep mempunyai daya saing baik dari sudut pandang keunggulan komparatif dan keunggulan kompetitif 
3. Apakah kebijakan pemerintah memberikan dampak dalam usaha Kacang hijau di Kabupaten Sumenep.

\section{Tujuan Penelitian}

Adapun tujuan dari penelitian ini adalah:

1. Melakukan analisis keuntungan

Kacang hijau di Kabupaten

Sumenep.

2. Melakukan analisis daya saing dari sudut pandang keunggulan komparatif dan keunggulan kompetitif.

3. Mengkaji dampak kebijakan pemerintah dalam usahatani Kacang hijau di Kabupaten Sumenep.

\section{METODE PENELITIAN}

\section{Penentuan Lokasi Penelitian}

Lokasi penelitian dilakukan di

Desa Saronggi dengan pertimbangan daerah tersebut merupakan salah satu daerah penghasil kacang hijau di Kecamatan Saronggi Kabupaten Sumenep..

\section{Sumber Data}

Sumber data pada penelitian ini digunakan adalah data primer diperoleh secara langsung dari lapangan atau dari pihak pertama.Data sekunder diperoleh dari studi pustaka, serta lembaga-lembaga yang berkaitan dalam penelitian.

\section{Tehnik Pengumpulan Data}

Metode pengambilan data dengan cara Interview dan observasi dengan mengamati secara langsung dilapangan.

\section{Metode Pengambilan Sampel}

Populasi dalam penelitan ini sebanyak 26 petani kacang hijau sedangkan Sampel dilakukan dengan menggunakan sampling acak sederhana

\section{Target Luaran}

Adapun target luaran penelitian ini terdiri atas :

1. Bahan informasi bagi petani yang ingin mengetahui keunggulan komparatif dan keunggulan kompetitif Kacang Hijau di Kabupaten Sumenep.

2. Bahan informasi dan pertimbangan bagi pemerintah, khususnya Dinas Pertanian dan Hortikultura

3. Bahan informasi tambahan untuk penelitian lebih lanjut demi pengembangan ilmu pengetahuan sesuai dengan kajian ilmu baik ilmu sosial dan ekonomi pada masa mendatang.

4. Dapat diorbitkan di Jurnal atau Prosideng

(simple random sampling) yaitu 24 petani dengan menggunakan rumus $90 \%$ dari jumlah Populasi menurut pendapat Soeratno dan Arsyad (1988).

\section{Metode Analisis Data}

Untuk menganalisis hipotesis pertama, kedua dan ketiga yaitu daya saing dan dampak kebijakan pemerintah terhadap usahatani kacang hijau digunakan alat analisis matrik kebijakan atau Policy Analysis Matrix (PAM) yang dikembangkan oleh Monke dan Pearson (1989). Model ini berupa suatu matrik yang disusun dengan memasukkan komponen-komponen utamanya penerimaan, biaya, dan profit (Soetriono, 2006)

Hasil analisis PAM akan memberikan informasi tentang profitabilitas, daya saing suatu komoditas baik dari efisiensi ekonomik (keunggulan komparatif) maupun efisiensi finansial, dampak kebijakan pemerintah terhadap sistem komoditi tersebut, dapat disimak pada tabel (Tabel 3.2). 
Tabel 3.1. Policy Analysis Matrix

\begin{tabular}{lc}
\hline Uraian & Penerimaan \\
\hline Harga Privat & $\mathrm{A}$ \\
Harga Sosial & $\mathrm{E}$ \\
Divergensi & $\mathrm{I}$ \\
\hline Sumber : Pearson et al, 2003 \\
Dari data tabel PAM di atas, \\
kemudian dapat dianalisis dengan berbagai \\
indikator sebagai berikut : \\
(1) $\quad$ Analisis keuntungan atau Private \\
Profitability (PP) \\
D = A-B-C \\
A = Penerimaan privat \\
B = Biaya input tradable privat \\
C = Biaya input non tradable privat
\end{tabular}

(2) Analisis keuntungan sosial Social Profitability (SP)

$\mathrm{H}=\mathrm{E}-\mathrm{F}-\mathrm{G}$

$\mathrm{E}=$ Penerimaan sosial

InputBiayalnput Non $\quad$ Profit

Tradable Tradable

(3) Efisiensi Finansial (Keuntungan Kompetitif) atau Private Cost Ratio:

$$
\mathrm{PCR}=\frac{\text { Biaya input non tradable privat }(\mathrm{C})}{\text { Penerimaan Privat }(\mathrm{A})-\text { Biaya input tradable Privat }(\mathrm{B})}
$$

Untuk mengetahui ada tidaknya keunggulan kompetitif kacang hijau digunakan kriteria Private Cost Ratio (PCR) yang menunjukkan daya saing petani pelaksana.

Kriteria pengambilan keputusan :

- Nilai PCR < 1, maka terdapat keunggulan kompetitif pada usahatani kacang hijau.

- Nilai PCR > 1, maka tidak terdapat keunggulan kompetitif pada usahatani kacang hijau.

(4) Analisis efisiensi domestik (Keunggulan Komparatif) atau Domestic Resource Cost Ratio

DRC $=\frac{\text { Biaya input non tradable Sosial }(G)}{\text { Penerimaan Sosial }(E) \quad-\text { Biaya Input tradable Sosial (F) }}$

Untuk menguji ada tidaknya keunggulan komparatif dari komoditas kacang hijau digunakan kriteria Domestic Resources Cost (DRC). Kriteria ini menyatakan nilai biaya sumberdaya dalam negeri yang diperlukan untuk meningkatkan hasil produksinya yang menghemat atau menghasilkan satu satuan devisa. Semakin kecil nilai koefisien DRC maka semakin efiisen aktifitas ekonomi yang dinalisis, ditinjau dari efisiensi pemanfaatan sumberdaya domestik.

Kriteria Pengambilan Keputusan :

Nilai DRC $<1$, maka terdapat keunggulan komparatif usahatani kacang hijau

Nilai DRC $>1$, maka tidak terdapat keunggulan komparatif usahatani kacang hijau. 
(5)

$\mathrm{OT}=$ Penerimaan privat $(\mathrm{A})-$ Penerimaan sosial (E)

(6) Input Transfer

IT $=$ Biaya input tradable privat $(\mathrm{B})-$

Biaya input tradable sosial (F)

(7) Transfer Faktor

(8) Nilai Transfer Bersih

NPT $=$ Keuntungan privat (D) Keuntungan sosial $(\mathrm{H})$

Nilai transfer bersih dapat menunjukkan tingkat ketidak efisienan dalam sistem pertanian yang disebabkan adanya kebijakan pemerintah.

Kriteria Pengambilan Keputusan :

- $\quad$ Nilai NPT positif, terdapat dampak positif dari kebijakan pemerintah.

- $\quad$ Nilai NPT negatif, tidak terdapat dampak positif dari kebijakan pemerintah

(9) Nominal Protection Coefficient on Tradable Output

Nilai NPCI merupakan ratio harga privat dari input yang diperdagangkan dengan harga sosialnya.

Kriteria Pengambilan Keputusan :

- $\quad$ Nilai NPCI $<1$, terdapat dampak positif dari kebijakan pemerintah.

- $\quad$ Nilai NPCI $>1$, tidak terdapat dampak positif dari kebijakan pemerintah.

EPC Effective Protection Coefficient

merupakan indikator yang memberikan nilai tambah terhadap komoditas kacang hijau

$$
\mathrm{EPC}=\frac{\text { Penerimaan privat }(\mathrm{A})-\text { Biaya input tradable privat }(\mathrm{B})}{\text { Penerimaan sosial }(\mathrm{E})-\text { Biaya input tradable sosial }(\mathrm{F})}
$$

Kriteria Pengambilan Keputusan :

- Nilai EPC < 1, tidak terdapat dampak positif dari kebijakan pemerintah.

- $\quad$ Nilai EPC > 1, terdapat dampak positif dari kebijakan pemerintah.

$$
\text { Profitability Coeficient }
$$

$$
\mathrm{PC}=\frac{\text { Keuntungan privat }(\mathrm{D})}{\text { Keuntungan sosial }(\mathrm{H})}
$$

Nilai Profitability Coefficient (PC) digunakan untuk mengukur pengaruh insentif dari seluruh kebijakan pemerintah.
Kriteria Pengambilan Keputusan :

- Nilai PC $<1$, tidak terdapat dampak positif dari kebijakan pemerintah.

- $\quad$ Nilai PC > 1, terdapat dampak positif dari kebijakan pemerintah. Subsidy Ratio to Producer

$$
\mathrm{SRP}=\frac{\text { Transfer bersih }(\mathrm{L})}{\text { Penerimaan sosial }(\mathrm{E})}
$$

SRP memberikan indikasi tentang seberapa besar kebijakan pemerintah meningkatkan/mengurangi biaya produksi. Kriteria Pengambilan Keputusan : 
$\bullet$

Nilai SRP positif, terdapat dampak positif dari kebijakan pemerintah.

- $\quad$ Nilai SRP negatif, tidak terdapat dampak positif dari kebijakan pemerintah.

\section{HASIL DAN PEMBAHASAN}

\section{Karakteristik Responden}

Petani sebagai pengelola sekaligus sebagai penentu kebijakan dalam menentukan alternatif kegiatan untuk

\section{Umur Petani}

Umur merupakan salah satu karakteristik yang melekat pada diri responden, dimana dengan bertambahnya umur maka akan menambah pengalaman dari seorang reponden. Distribusi umur responden kategori muda ( $<40$ th) sebanyak 7 responden, sedang (40-60 th) sebanyak 13 responden, dan tua (> 60 th) sebanyak 8 responden. Dengan total keseluruhan 28 responden.

\section{Jumlah Anggota Keluarga}

Distribusi jumlah anggota keluarga responden di daerah penelitian yaitu jumlah anggota keluarga sebagai sumberdaya tenaga kerja yang merupakan keuntungan yang tidak dinilai secara ekonomi oleh keluarga. Kategori terbanyak jumlah anggota keluarga adalah kategori sedang (3-4 orang) dengan jumlah responden sebanyak 14 responden. Sedangkan jumlah anggota keluarga kecil (< 3 orang) sebanyak 7 responden dan jumlah anggota keluarga besar (> 4 orang) hanya 7 responden.

\section{Jumlah Kepemilikan Lahan}

Jumlah rata-rata kepemilikan secara keseluruhan sebanyak 0,9 ha. Responden yang memiliki lahan kategori sedikit $(<0,6$ ha) sebanyak 2 responden, sedangkan yang memaksimalkan keuntungan usahataninya. Oleh karena itu beberapa faktor sosial ekonomi yang melekat padanya diantaranya umur, jumlah anggota keluarga serta jumlah kepemilikan lahan dalam mengelola usahatani mempengaruhi terhadap keputusan yang diambil. Faktor-faktor diatas perlu dikaji untuk mengetahui layak atau tidaknya seorang responden untuk diambil

memiliki lahan kategori sedang $(0,6-1,2$ ha) sebanyak 24 responden dan kategori banyak (> 1,2 ha) sebanyak 2 responden.

\section{Hasil Analisis Dan Pembahasan}

\subsubsection{Keuntungan Privat dan Sosial Usahatani Kacang Hijau}

Keuntungan adalah perbedaan antara penerimaan dan biaya. Efisien tidaknya usahatani dapat ditinjau dari dua segi, yaitu pertama secara privat yang disebut dengan keuntungan privat (pada harga pasar aktual) dan kedua secara sosial yang disebut dengan keuntungan sosial (pada harga sosial). Tujuan penghitungan efisien usahatani kacang hijau melalui analisis PAM adalah untuk mengetahui apakah terdapat efisiensi pada usahatani kacang hijau di Kecamatan Saronggi Kabupaten Sumenep baik secara finansial dan ekonomi. Kriteria pengambilan keputusan didasarkan pada nilai profitabilitas sistem bernilai positif, yang menyatakan bahwa terdapat efisiensi usahatani kacang hijau. Hasil analisis profitabilitas usahatani usahatani kacang hijau di Kecamatan Saronggi dapat dilihat pada Tabel 4.1.

Tabel 4.1. Nilai Keuntungan Usahatani Kacang Hijau Kecamatan Saronggi

\begin{tabular}{lllll}
\hline & \multirow{2}{*}{ Pendapatan } & \multicolumn{2}{c}{ Biaya } & \multirow{2}{*}{ Keuntungan } \\
\cline { 3 - 5 } & & Input & Faktor & \\
\hline Privat & $19.998 .819,07$ & $604.292,22$ & $4.863 .162,22$ & $14.531 .364,63$ \\
Sosial & $22.206 .756,26$ & $914.573,68$ & $3.178 .430,00$ & $18.113 .752,59$ \\
Divergensi & $2.207 .937,19$ & $-310.281,46$ & $1.684 .732,23$ & $-3.582 .387,96$ \\
\hline
\end{tabular}

Sumber :Data primer diolah, 2020 
Berdasarkan tabel di atas dapat diketahui bahwa nilai keuntungan privat adalah Rp. 14.531.364,63,-. Berarti usahatani kacang hijau di Kecamatan Saronggi menguntungkan dan layak diusahakan karena menunjukkan nilai yang positif. Dan keuntungan sosial usahatani kacang hijau di Kecamatan Saronggi yaitu sebesar Rp. 18.113.752,59,-. Hal ini menunjukan nilai yang positif, dan dapat diartikan bahwa usahatani kacang hijau menguntungkan dan layak untuk diusahakan.

Biaya input tradable usahatani kacang hijau terdiri dari biaya bibit dan biaya pupuk yang digunakan. Sedangkan biaya faktor domestik usahatani kacang hiijau merupakan total dari berbagai biaya yang terdiri dari biaya sewa lahan, tenaga kerja, alat produksi, modal kerja, dan biaya penyusutan.

\subsubsection{Daya Saing Usahatani Kacang Hijau}

Daya saing suatu produk pada umumnya dapat diukur dengan dua cara yaitu keunggulan komparatif dan keunggulan kompetitif. Keunggulan komparatif dan keunggulan kompetitif kacang hijau dapat diketahui dari nilai koefisien PCR (Privat Cost Ratio) dan DRC (Domestic Resource Ratio). Hasil analisis keunggulan komparatif dan keunggulan kompetitif dapat dilihat dengan menggunakan Matrik Analisis Kebijakan (PAM).

A. Keunggulan Komparatif Usahatani Kacang hijau

Keunggulan komparatif merupakan ukuran normatif, yaitu mengukur daya saing pada kondisi pasar persaingan bebas dan tanpa distorsi. Negara yang mempunyai opportunity cost relatif rendah akan lebih efisien dan mempunyai keunggulan komparatif, karena negara tersebut mempunyai keunggulan dalam mengalokasikan biaya jika dibandingkan dengan produsen lainnya, dan mereka akan kompetitif secara internasional.
Keunggulan komparatif merupakan potensi keunggulan yang dimiliki oleh wilayah atau komoditas karena sumberdaya yang dimilikinya.

Salah satu alat untuk mengukur keunggulan komparatif adalah dengan DRC (Domestic Resource Ratio). Analisis DRC ini digunakan untuk mengukur berapa besarnya satu-satuan devisa yang dapat dihemat bila produk tersebut diproduksi di dalam negeri. Nilai DRC lebih kecil dari satu berarti produksi usahatani kacang hijau efisien dipandang dari segi penggunaan sumberdaya domestik. Secara ekonomi memproduksi kacang hijau dalam negeri lebih efisien dan menguntungkan daripada melakukan impor, sebaliknya jika nilai DRC lebih besar dari satu, berarti memproduksi kacang hijau di dalam negeri tidak efisien dipandang dari segi pemakaian sumber daya domestik.

Analisis Domestic Resource Cost Analysis (DRC), dihitung berdasarkan harga sosial atau berdasarkan harga pasar internasional. Hasil produksi dan pendapatan yang diperdagangkan secara internasional penaksiran sosial didasarkan pada harga pasaran dunia, c.i.f harga impor untuk komoditas impor dan f.o.b untuk komoditas ekspor.

Hasil analisis PAM diketahui bahwa angka DRC usahatani kacang hijau di daerah penelitian lebih kecil dari satu yaitu sebesar 0.1493. Hasil ini membuktikan hipotesis yang menyatakan bahwa usahatani kacang hijau memiliki keunggulan komparatif. Nilai DRC sebesar 0.1493, menunjukkan bahwa usahatani kacang hijau di daerah penelitian dari segi ekonomi efisien dalam menggunakan sumber daya domestik, sebab untuk menghasilkan devisa sebesar satu-satuan hanya dibutuhkan biaya faktor domestik sebesar 0.1493 satuan. Untuk menghasilkan satu-satuan output dapat dihemat sebesar 0,8482 atau sebesar $\mathrm{Rp}$ 13.860. Nilai DRC diatas berdasarkan 
asumsi harga bayangan nilai tukar uang (SER) $(\mathrm{Rp} / \$)$ sebesar Rp. 16.341.

B. Keunggulan Kompetitif Kacang Hijau

Keunggulan kompetitif merupakan ukuran aktual, yaitu mengukur daya saing pada kondisi pasar yang berlaku tanpa mempermasalahkan ada tidaknya distorsi pasar. Salah satu indikator keunggulan kompetitif yang paling sederhana adalah rasio harga produksi dalam negeri dengan produk yang sama di luar negeri. Suatu produk yang memiliki keunggulan komparatif bisa terjadi tidak memiliki keunggulan kompetitif apabila ada hambatan-hambatan yang bersifat disinsentif.

Sebaliknya suatu produk yang tidak memiliki keunggulan komparatif bisa terjadi memiliki keunggulan kompetitif apabila pemerintah memberikan proteksi terhadap produk yang bersangkutan. Proteksi perdagangan mencakup semua insentif perdagangan baik kuota, tarif, maupun subsidi. Semua bentuk perdagangan ini dapat menimbulkan distorsi pasar yaitu mencegah terjadinya pasar persaingan bebas.

Keunggulan kompetitif dapat diketahui melalui Privat Cost Ratio (PCR) . PCR merupakan rasio antara biaya faktor domestik dengan nilai tambah output dari biaya faktor domestik yang diperdagangkan pada harga tingkat produsen. Nilai PCR menunjukkan keunggulan kompetitif apabila sesuai dengan kriteria pengambilan keputusan PCR kurang dari satu.

Hasil analisis menunjukkan bahwa usahatani kacang hijau yang ditanam memiliki keunggulan kompetitif. Hal ini dibuktikan dari nilai PCR kurang dari satu.

Berdasarkan perhitungan PAM dapat diketahui usahatani kacang hijau memiliki nilai PCR 0,1493 yang berarti untuk menghasilkan satu-satuan nilai tambah output pada harga privat diperlukan korbanan faktor sumberdaya domestik sebesar 0,1493 satuan atau untuk menghasilkan satu-satuan output dapat dihemat sebesar 0,8507 atau sebesar Rp 13.806. Nilai PCR diatas berdasarkan asumsi nilai tukar rupiah terhadap US\$ = Rp. 16.230.

Berdasarkan hasil analisa PCR, dapat diketahui bahwa usahatani kacang hijau di daerah penelitian menghasilkan kacang hijau dengan kemampuan berkompetisi lebih baik dibanding usahatani kacang hijau dipasaran Indonesia. Hal ini terjadi karena usahatani kacang hijau di daerah penelitian dinilai lebih memiliki kesesuaian dengan lahan dan sumber daya domestik. Adanya kesesuaian lahan dan sumberdaya domestik memungkinkan adanya efisiensi dalam menggunakan input tradable. Dengan demikian penggunaan faktor domestik lebih optimal dan pengeluaran untuk biaya input lebih rendah.

\subsubsection{Dampak Kebijakan Pemerintah Terhadap Usahatani Kacang hijau di Kabupaten Sumenep \\ Dampak kebijakan pemerintah} terhadap usahatani kacang hijau dapat diketahui melalui tiga aspek, yaitu: (a) Kebijakan pemerintah terhadap input tradable dan faktor domestik, (b) Kebijakan pemerintah terhadap output, dan (c) Kebijakan pemerintah terhadap output dan input secara keseluruhan. Hasil kajian dari ketiga aspek tersebut dapat digunakan sebagai penentu ada tidaknya kebijakan pemerintah terhadap usahatani kacang hijau serta mengetahui dampak kebijakan tersebut terhadap usahatani kacang hijau di Kabupaten Sumenep.

A. Kebijakan Pemerintah Terhadap Input Tradable dan Faktor Domestik

Kebijakan pemerintah terhadap input tradable dapat dilihat dari nilai Nominal Protection Coefficient Input (NPCI) dan Transfer Input (IT). Kebijakan proteksi terhadap input dapat berupa kebijakan perdagangan, subsidi, dan pajak yang diberikan pemerintah terhadap petani. Sedangkan bentuk divergensi 
lainnya bisa disebabkan adanya distorsi pasar.

Rasio ini menunjukkan seberapa besar harga domestik dari input tradable berbeda dengan harga sosialnya. Bila NPCI bernilai lebih besar dari satu, biaya input domestik lebih mahal dari harga sosialnya. Dengan kata lain usahatani kacang hijau seolah-olah dibebani pajak oleh kebijakan yang ada. Bila NPCI lebih kecil dari satu, harga domestik lebih rendah dari harga sosialnya, dan usahatani kacang hijau seolah-olah disubsidi oleh kebijakan yang ada.

Hasil analisis NPCI dari penelitian yang telah dilakukan dapat dilihat pada tabel 4.2. di bawah ini.

Tabel 4.2. Transfer Input Tradable Usahatani Kacang hijau di Kabupaten Sumenep

\begin{tabular}{|c|c|c|c|c|c|c|c|}
\hline \multirow[b]{2}{*}{ Usahatani } & \multicolumn{6}{|c|}{ Input Tradable } & \multirow[b]{2}{*}{ NPCI } \\
\hline & $\begin{array}{l}\text { Benih } \\
\text { (Rp/ha) }\end{array}$ & $\begin{array}{l}\text { Organik } \\
\text { (Rp/ha) }\end{array}$ & $\begin{array}{c}\text { Urea } \\
\text { (Rp/ha) }\end{array}$ & $\begin{array}{c}\text { SP-36 } \\
\text { (Rp/ha) }\end{array}$ & $\begin{array}{c}\text { NPK } \\
\text { (Rp/ha) }\end{array}$ & $\begin{array}{c}\text { Total } \\
\text { (Rp/ha) }\end{array}$ & \\
\hline Privat & 264169.34 & 70389.31 & 65955.71 & 50423.61 & 153354.25 & 604292.22 & 0.661 \\
\hline Sosial & 264169.34 & 70389.31 & 92565.78 & 87047.42 & 400401.82 & 914573.68 & \\
\hline Divergensi & - & - & -26610.1 & -36623.8 & -247047.6 & -310281.5 & \\
\hline
\end{tabular}

Sumber: Data primer, diolah 2020

Tabel 4.2. dapat diketahui bahwa nilai NPCI usahatani kacang hijau adalah sebesar 0,661 , yang berarti bahwa petani membeli input tradable dengan harga $44 \%$ lebih rendah dari harga input sosialnya. Hal ini menunjukkan bahwa kebijakan pemerintah terhadap input tradable berdampak positif terhadap usahatani kacang hijau di Kabupaten Sumenep.

Dari nilai divergensi diketahui pula bahwa petani kacang hijau harus membayar input tradable berupa Urea, SP36 dan NPK lebih murah dari harga sosialnya.

Divergensi akibat lebih murahnya harga yang harus dibayarkan petani dengan harga yang sebenarnya mengindikasikan adanya subsidi yang diberikan pemerintah. Sebaliknya, bila harga yang harus dibayarkan petani lebih mahal dari harga yang sebenarnya mengindikasikan adanya pajak yang dibebankan pemerintah. Dalam hal ini pemerintah memberikan subsidi pupuk terhadap petani kacang hijau.

Kebijakan pemerintah terhadap input tradable benih dan pupuk organik untuk usahatani kacang hijau di Kabupaten Sumenep sama sekali tidak mempengaruhi harga di tingkat petani, hal ini dibuktikan dari nilai divergensi sebesar nol. Nilai tersebut menyatakan bahwa pemerintah tidak memberikan subsidi maupun pajak untuk benih kacang hijau dan pupuk organik, sehingga harga yang harus dibayarkan petani adalah sama dengan harga sosialnya.

Hal ini disebabkan benih yang diterima oleh petani adalah benih lokal. Oleh karena itu harga sosialnya sama dengan harga privatnya. Sedangkan pupuk organik merupakan pupuk yang berasal dari domestik yang diperoleh kotoran ternak milik petani. Untuk pupuk organik tidak ada kebijakan pemerintah yang dapat mempengaruhi harga pupuk organik yang digunakan.

Sedangkan hasil analisis Transfer Input (IT) yang diperoleh pada penelitian ini adalah sebesar Rp. - 310.281,46. Angka IT menunjukkan nilai negatif yang disebabkan oleh subsidi atas pupuk sekitar $44 \%$, sehingga total biaya input tradable yang dikeluarkan hanya $46 \%$ dari biaya seharusnya.

Kebijakan pemerintah terhadap faktor domestik (input non tradable) ditunjukkan dari penggunaan tenaga kerja, alat produksi, modal, lahan dan biaya penyusutan yang digunakan selama 
berusahatani kacang hijau secara jelas dapat dilihat pada Tabel 4.3.

Faktor domestik tenaga kerja dan lahan yang dikeluarkan dalam memproduksi kacang hijau di Kabupaten Sumenep menunjukkan adanya divergensi. Pada faktor domestik tenaga kerja, nilai divergensi adalah sebesar Rp. 187.589,95 lebih tinggi dari upah tenaga kerja yang seharusnya dikeluarkan selama melakukan produksi.

Pengaruh ini disebabkan karena dalam melakukan kegiatan usahatani kacang hijau, petani menggunakan tenaga tidak terampil. Upah yang diberikan kepada tenaga kerja tidak terampil mencerminkan upah sosial yang sesungguhnya. Penyimpangan ini disebabkan oleh adanya kebijakan pemerintah seperti adanya tingkat upah minimum yang menyebabkan tingkat upah yang diterima lebih tinggi dari tingkat upah sebenarnya.

Tabel 4.3. Dampak Kebijakan Pemerintah Terhadap Faktor Domestik Usahatani Kacang hijau di Kabupaten Sumenep

\begin{tabular}{|c|c|c|c|c|c|c|}
\hline \multirow[b]{2}{*}{ Usahatani } & \multicolumn{6}{|c|}{ Faktor Domestik } \\
\hline & $\begin{array}{l}\text { Sewa } \\
\text { Lahan }\end{array}$ & $\begin{array}{c}\text { Tenaga } \\
\text { Kerja }\end{array}$ & Alat Produksi & Modal & Penyusutan & Total \\
\hline Privat & 619861.18 & 2831302.54 & 833105.94 & 412271.37 & 166621.19 & 4863162.22 \\
\hline Sosial & 526882.00 & 1341930.22 & 833105.94 & 309890.65 & 166621.19 & 3178430.00 \\
\hline Divergensi & 92979.18 & 1489372.32 & - & 102380.72 & - & 1684732.23 \\
\hline
\end{tabular}

Sumber: data primer, diolah 2020

Tabel 4.3. menunujukkan bahwa faktor domistik Lahan, tenaga kerja dan modal yang dikeluarkan dalam usahatani kacang hijau menunjukkan adanya divergensi. Faktor sewa lahan nilai divergensinya adalah negatif yaitu Rp. - 92.979,18. Faktor tenaga kerja nilai divergensinya adalah negatif yaitu Rp. - 148.9372,32, sedangkan faktor modal nilai divergensinya Rp. 102.380,72.

Perolehan nilai negatif ini disebabkan karena yang dikeluarkan oleh petani sebagian besar berasal dari pinjaman baik yang berasal dari bank maupun dari pinjaman pada kelompok tani. Pengaruh ini akan menyebabkan adanya perbedaan suku bunga nominal yang dibayarkan pertahun sebesar $12 \%$, sedangkan suku bungan sosial pertahun sebesar 9,02\%. Lebih tingginya suku bunga privat disebabkan adanya pemasukkan keuntungan bagi pihak pemberi modal.
B. Kebijakan
Pemerintah Terhadap
Output

Terjadinya penerimaan finansial lebih besar dari penerimaan ekonomi merupakan dampak dari kebijakan harga dan mekanisme pasar yang berpengaruh positif terhadap harga aktual komoditas kacang hijau di tingkat petani, maka secara finansial penerimaan petani lebih tinggi daripada penerimaan ekonominya dan keunggulan komoditas kacang hijau akan bertambah baik. Sebaliknya, jika pengaruh dari kebijakan harga dan mekanisme pasar tersebut menyebabkan harga kacang hijau ekspor lebih tinggi dari harga kacang hijau domestik akan berdampak negatif terhadap penerimaan petani dan keunggulan kacang hijau domestik.

Untuk mengetahui sejauh mana pengaruh kebijakan pemerintah terhadap mekanisme pasar pada output kacang hijau, dapat diketahui dengan nilai NPCO (Nominal Protection Coefficient Ouput). Kriteria pengambilan keptusan didasarkan pada nilai NPCO yang mempunyai nilai lebih dari satu, hal ini menyatakan bahwa terdapat kebijakan pemerintah yang memproteksi ouput atau harga privat output yang diterima petani lebih tinggi dari harga sosial. 
Hasil analisis dari penelitian secara jelas dapat dilihat pada tabel dibawah ini.
Tabel 4.4. Transfer Output Usahatani Kacang hijau di Kabupaten Sumenep

\begin{tabular}{|l|r|r|}
\hline \multicolumn{1}{|c|}{ Usahatani } & \multicolumn{1}{c|}{$\begin{array}{l}\text { Output } \\
\text { (Rp/ha) }\end{array}$} & NPCO \\
\hline Privat & $19.998 .819,07$ & 0,9006 \\
Sosial & $22.206 .756,26$ & \\
Divergensi & $220.7937,19$ & \\
\hline
\end{tabular}

Sumber : data primer, diolah 2020

Tabel 4.4. terlihat bahwa nilai koefisien NPCO untuk usahatani kacang hijau lebih kecil dari satu yaitu sebesar 0.9006. Nilai ini mengindikasikan bahwa petani kacang hijau di daerah penelitian tidak menerima proteksi output dari instrument kebijakan pemerintah dan mekanisme pasar output yang berlaku pada tahun 2020, dimana harga kacang hijau domestik pada saat itu lebih rendah dari harga sosialnya.

Tingkat penerimaan yang diterima petani kacang hijau memperoleh harga 10 $\%$ lebih rendah dari harga dunia. Rendahnya harga kacang hijau yang dijual oleh petani jika dibandingkan dengan harga sosial disebabkan karena kacang hijau yang dijual oleh petani kualitasnya lebih rendah daripada kacang hijau yang diekspor. Hal ini disebabkan karena kacang hijau yang dijual oleh petani kebanyakan merupakan kebutuhan domestik. Selain itu rendahnya harga kacang hijau di tingkat petani..

C. Kebijakan Pemerintah Terhadap Output dan Input secara Keseluruhan

Kebijakan output dan input secara keseluruhan dapat dilihat melalui beberapa indikator yaitu Effective Protection Coefficient (EPC), Net Protection Transfer
(NPT), Profitability Coefficient (PC) dan Subsidy Ratio to Producer (SRP).

1. Effective Protection Cofficient (EPC) Efffective Protection Cofficient (EPC) atau analisis proteksi efektif digunakan untuk mengetahui pengaruh dari keseluruhan kebijakan pemerintah dan mekanisme pasar input output, apakah memberikan insentif atau disinsentif terhadap usahatani kacang hijau. Nilai EPC pada dasarnya bertujuan untuk menggambarkan bagaimana kebijakan pemerintah mampu melindungi atau menghambat produk domestik secara efektif.

Bila nilai EPC lebih besar dari satu berati dampak bersih kebijakan pemerintah dalam pembentukan harga dan mekanisme pasar komoditi telah memberikan insentif (perlindungan) terhadap petani kacang hijau untuk mengembangkan usahataninya. Sebaliknya, jika nilai EPC lebih kecil dari satu berarti dampak bersih kebijakan pemerintah tersebut menimbulkan disinsentif terhadap pengembangan usahatani kacang hijau.

Nilai EPC juga dapat menjelaskan seberapa persen nilai tambah yang dinikmati dari nilai tambah sosialnya. Nilai EPC pada usahatani kacang hijau ditunjukkan pada Tabel 4.5 di bawah ini.

Tabel 4.5. Nilai EPC Usahatani Kacang hijau di Kabupaten Sumenep

\begin{tabular}{|l|c|c|c|}
\hline \multicolumn{1}{|c|}{ Usahatani } & $\begin{array}{c}\text { Output } \\
\text { (Rp/ha) }\end{array}$ & $\begin{array}{c}\text { Input } \\
\text { (Rp/ha) }\end{array}$ & EPC \\
\hline Privat & $19.998 .819,07$ & 604.292 .22 & 0,9109 \\
Sosial & $22.206 .756,26$ & $914.573,68$ & \\
Divergensi & $2.207 .937,19$ & $-310.281,46$ & \\
\hline
\end{tabular}

Sumber: data primer diolah 2020
Tabel 4.5 menujukkan bahwa nilai EPC untuk usahatani kacang hijau 
memiliki nilai EPC lebih kecil dari satu yaitu sebesar 0,9109. Nilai tersebut menunjukkan bahwa kebijakan pemerintah menimbulkan diinsentif terhadap petani kacang hijau atau kebijakan pemerintah tidak dapat memberikan proteksi terhadap petani kacang hijau di Kabupaten Sumenep. Hal ini berarti harga output kacang hijau yang diterima petani lebih rendah dari harga pasar dunia. Atau dengan kata lain bahwa dampak kebijakan pemerintah dalam pembentukan harga dan mekanisme pasar komoditi tidak memberikan insentif (perlindungan) kepada petani kacang hijau. Hal ini dibuktikan dengan nilai EPC lebih kecil dari satu, yang dapat diartikan pula bahwa nilai tambah yang dinikmati petani lebih rendah dari nilai tambah sosialnya.

2. Net Protection Transfer (NPT)

Net Protection Transfer (NPT) merupakan nilai yang menggambarkan

\begin{tabular}{|r|c|c|c|c|c|}
\hline Usahatani & $\begin{array}{c}\text { Output } \\
(\mathrm{Rp} / \mathrm{ha})\end{array}$ & $\begin{array}{c}\text { Input } \\
(\mathrm{Rp} / \mathrm{ha})\end{array}$ & $\begin{array}{c}\text { Faktor } \\
\text { Domestik } \\
(\mathrm{Rp} / \mathrm{ha})\end{array}$ & $\begin{array}{c}\text { Keuntungan } \\
(\mathrm{Rp} / \mathrm{ha})\end{array}$ & NPT \\
\hline Privat & $19.998 .819,07$ & 604.292 .22 & 4.863 .162 .22 & $114.531 .364,63$ & $3,582,387.96$ \\
Sosial & $22.206 .756,26$ & $914.573,68$ & $3.178 . .430 .00$ & $118.113 .752,59$ & \\
Divergensi & $2.207 .937,19$ & $310.281,46$ & 1.684 .732 .23 & $-3.582 .387,96$ & \\
\hline
\end{tabular}

Sumber: data primer, diolah 2020

Tabel 4.6. menunjukkan bahwa nilai NPT yang merupakan gambaran tambahan surplus produsen diketahui nilai transfer bersih untuk usahatani kacang hijau menunjukkan angka negatif sebesar Rp. -3.582.387,96. Nilai tersebut menunjukkan bahwa kebijakan pemerintah terhadap input dan output tradable secara keseluruhan berdampak negatif atau merugikan bagi petani kacang hijau. Hal ini disebabkan harga output kacang hijau di tingkat petani lebih rendah dari harga yang seharusnya diterima petani atau harga sosial.

3. Profit Coefficient (PC) tambahan surplus produsen atau berkurangnya surplus produsen yang diakibatkan oleh kebijakan pemerintah, dihitung dari hasil pengurangan antara keuntungan bersih yang diterima produsen dengan keuntungan bersih sosial. Nilai transfer bersih output dapat dilihat dari nilai divergensi keuntungan privat dan sosial.

Pengambilan keputusan didasarkan pada hasil analisis NPT positif yang menunjukkan adanya dampak positif dari kebijakan pemerintah. Sebaliknya jika NPT bernilai negatif berarti tidak terdapat dampak positif dari kebijakan pemerintah. Hasil analisis NPT dapat dilihat pada Tabel 4.6.

Tabel 4.6. Nilai NPT Usahatani Kacang hijau di Kabupaten Sumenep

\begin{tabular}{|c|c|c|c|c|c|}
\hline Usahatani & Output & Input & $\begin{array}{c}\text { Faktor } \\
\text { Domestik }\end{array}$ & Keuntungan & PC \\
\hline
\end{tabular}




\begin{tabular}{|r|c|c|c|c|c|}
\cline { 6 - 7 } & $(\mathrm{Rp} / \mathrm{ha})$ & $(\mathrm{Rp} / \mathrm{ha})$ & $(\mathrm{Rp} / \mathrm{ha})$ & $(\mathrm{Rp} / \mathrm{ha})$ & \\
\hline Privat & $19.998 .819,07$ & 604.292 .22 & 4.863 .162 .22 & $114.531 .364,63$ & 0,8022 \\
Sosial & $22.206 .756,26$ & $914.573,68$ & $3.178 . .430 .00$ & $118.113 .752,59$ & \\
Divergensi & $2.207 .937,19$ & $310.281,46$ & 1.684 .732 .23 & $-3.582 .387,96$ & \\
\hline
\end{tabular}

Sumber: data primer, diolah 2020

Tabel 4.7 diketahui nilai PC untuk usahatani kacang hijau memiliki nilai PC sebesar 0,8022 atau lebih kecil dari satu yang berarti petani menerima keuntungan privat lebih rendah $20 \%$ dari keuntungan sosialnya. Hasil ini menunjukkan bahwa keuntungan privat usahatani kacang hijau di Kabupaten Sumenep lebih rendah dari keuntungan sosialnya. Hal ini berarti kebijakan pemerintah pada usahatani kacang hijau tidak dapat menambah penerimaan petani kacang hijau. Selama ini output kacang hijau masih lebih banyak di konsumsi dalam negeri. Berdasarkan Nilai PC yang bernilai kurang dari satu tersebut, untuk kacang hijau diharapkan bisa dijual ke luar

\begin{tabular}{|r|c|c|}
\hline Usahatani & $\begin{array}{c}\text { Output } \\
\text { (Rp/ha) }\end{array}$ & $\begin{array}{c}\text { Input } \\
\text { (Rp/ha) }\end{array}$ \\
\hline Privat & $19.998 .819,07$ & 604.292 .22 \\
Sosial & $22.206 .756,26$ & $914.573,68$ \\
Divergensi & $2.207 .937,19$ & $310.281,46$ \\
\hline
\end{tabular}

Sumber: data primer, diolah 2020

Berdasarkan nilai SRP dan NPT, PC maupun EPC diketahui bahwa kebijakan pemerintah memberikan dampak negatif atau tidak berpihak baik dari segi output dan input tradable terhadap petani kacang hijau di Kabupaten Sumenep. Artinya, pengaruh kebijakan pemerintah dan mekanisme pasar berdampak negatif terhadap struktur biaya produksi. Hal ini menunjukkan bahwa kebijakan yang dilakukan pemerintah tidak membawa negeri sehingga bisa menambah keuntungan petani kacang hijau. Alasan lain dapat dinyatakan bahwa adanya kebijakan pemerintah menyebabkan keuntungan privat lebih rendah dari keuntungan sosialnya.

4. Subsidy Ratio to Producer (SRP) Subsidy Ratio to Producer (SRP) adalah rasio yang digunakan untuk mengukur seluruh efek transfer. Rasio ini merupakan perbandingan antara transfer bersih dengan nilai output pada tingkat harga dunia, atau SRP menunjukkan sejauhmana pendapatan dari sistem meningkat atau menurun karena pengaruh transfer. Nilai SRP dapat dilihat pada Tabel 4.8.

Tabel 4.8. Nilai SRP Usahatani Kacang hijau di Kabupaten Sumenep

\begin{tabular}{|c|c|c|}
\hline $\begin{array}{c}\text { Faktor } \\
\text { Domestik } \\
(\mathrm{Rp} / \mathrm{ha})\end{array}$ & $\begin{array}{c}\text { Keuntungan } \\
(\mathrm{Rp} / \mathrm{ha})\end{array}$ & SRP \\
\hline 4.863 .162 .22 & $114.531 .364,63$ & $-0,1613$ \\
$3.178 . .430 .00$ & $118.113 .752,59$ & \\
1.684 .732 .23 & $-3.582 .387,96$ & \\
\hline
\end{tabular}

dampak positif pada petani kacang hijau di daerah penelitian

\section{KESIMPULAN}

Berdasarkan hasil analisis dan pembahasan secara spesifik dapat diambil beberapa kesimpulan sebagai berikut:

1. Usahatani kacang hijau yang ditanam di Desa Saronggi Kecamatan Saronggi Kabupaten Sumenep menguntungkan dan mampu bersaing, serta layak untuk diusahakan. 
2. Usahatani kacang hijau memiliki keunggulan komparatif dan keunggulan kompetitif

3. Kebijakan pemerintah tidak memberikan dampak positif atau tidak berpihak baik dari segi output dan input tradable terhadap petani kacang hijau di Kabupaten Sumenep.

\section{DAFTAR PUSTAKA}

Badan Pusat Statistik. 2018. Luas Panen Kacang Hijau Menurut Provinsi, 2014 - 2018. Jakarta. www.bps.go.id. Diakses pada tanggal 18 Oktober 2019

Badan Pusat Statistik Kabupaten Sumenep. 2019. Sumenep Dalam Angka 2019. Sumenep. www.bps.go.id. Diakses pada tanggal 22 Oktober 2019

Balitkabi. 2019. Kacang Hijau Indonesia Mendunia, Kementan Lepas Ekspor Kacang Hijau ke China dan Philipina. balitkabi.litbang.pertanian.go.id. Diakses pada tanggal 16 Oktober 2019

BPTP Sulawesi Selatan. 2018. Budidaya Kacang Hijau. sulsel.litbang.pertanian.go.id.

Diakses pada tanggal 12 Desember 2019

Hastuti D.P, Supriyono, dan Hartati S. 2018. Pertumbuhan dan Hasil Kacang Hijau (Vigna radiata, L.) pada Beberapa Dosis Pupuk Organik dan Kerapatan Tanam. Journal of Sustainable Agriculture, Vol. 33, No. 2, Agustus 2018 : 89-95

Mardianto dan Edi Firnando. 2017. Analisis Keunggulan Komparatif dan Kompetitif Beras Solok Organik. Jurnal AGRIFO. Vol.
2, No. 2, November $2017: 9-$ 17

Monke, Eric A dan Scott R Person. 1989. The Policy Analisys Matrix for Agriculture Development. Cornel University Press.

Nurayati A. 2015. Analisis Daya Saing dan Kebijakan Pemerintah Terhadap Usahatani Padi, Jagung dan Kedelai Provinsi Jawa Tengah. Skripsi. Semarang : Fakultas Ekonomi Universitas Negeri Semarang

Pearson S, Gotsch C, Bahri S. 2005. Aplikasi Policy Analysis Matrix Pada Pertanian IndonesiaI. Jakarta : Yayasan Obor Indonesia

Rukmana R. 1997. Kacang Hijau Budi Daya dan Pascapanen. Yogyakarta : Kanisius

Pearson, S.R, Gotsch, C, Bahri, S. 2003. Sumber: Pearson et al (2003), Aplikasi Policy Analysis Matrix Pada Pertanian Indonesia. Tersedia di: http://www. macrofoodpolicy.com.

Soeratno dan Arsyad, L 1988. Metodelogi Penelitian. Untuk Ekonomi dan Bisnis. Yogyakarta No. 1, Juni $2017: 79-86$

Soetriono, 2006. Daya Saing Pertanian dalam Tinjauan Analisis. Penerbit Bayumedia Publishing, Malang.

Tetik A, dan Y.M. Fallo. 2016. Analisis Pendapatan Usahatani Kacang Hijau di Kecamatan Wewiku Kabupaten Malaka. Jurnal Agribisnis Lahan Kering, Vol. 1 No. 3, Juli $2016: 53-54$ 